\title{
Ecological effectiveness of oil spill countermeasures: how clean is clean?*
}

\author{
Jenifer M. Baker \\ Ruyton-XI-Towns, Shrewsbury SY4 1LA, UK
}

\section{INTRODUCTION}

In the aftermath of an oil spill, what should drive the clean-up response and when is it reasonable to stop cleaning? Furthermore, which of the diversity of oil spill clean-up technologies as described in other chapters of this volume might be employed most effectively to achieve this elusive goal? These are complex questions involving chemical, ecological, socio-economic and political considerations and there are no simple answers. It is important to identify and build consensus for recommended clean-up protocols. These recommendations should be based on the considerable experience that has accumulated over the past 30 years. It is the intent of this paper to identify key points and issues with respect to ecological aspects, bearing in mind that these in turn commonly relate to socio-economic aspects.

\section{BACKGROUND LEVELS OF HYDROCARBONS AND THE DIFFICULTY OF DEFINING 'CLEAN'}

Myers \& Gunnerson [1] concluded that both biogenic and petrogenic hydrocarbons are ubiquitous: this conclusion has been amply justified by subsequent analytical data [2]. Higher concentrations of hydrocarbons in water, sediments and organisms are found in nearshore waters, particularly in urban and industrialised bays and inlets (because of the proximity to chronic inputs). It also is clear that sediments or organisms may accumulate hydrocarbons in higher concentrations than does water. It follows that the definition of clean in the aftermath of an oil spill cannot mean a complete absence of either total hydrocarbons or petroleum hydrocarbons. It therefore is necessary to refer either to specified concentrations or to a variety of other criteria. For example, clean may be defined as petroleum hydrocarbon concentrations that:

- Do not exceed normal background levels for a particular location;

- Do not exceed statutory limits;

- Are not lethal to specified organisms;

- Do not cause deleterious sublethal effects to specified organisms;

- Do not cause tainting of food organisms;

- Have no detectable impact on the function of an ecosystem;

- Do not impair the human use of an area;

- Are not visible to the human eye; and,

- Cannot be reduced by enhanced clean-up actions without causing an overall retardation of recovery.

There are many possible definitions of clean that carry different perceptions of risk, including risk to ecosystem stability, the productivity of ecosystem components, human health, or local economies. There are difficulties to overcome with definitions of clean. There is great subjectivity inherent in the eyes of the evaluator, and the values placed on affected resources. There is inaccuracy in the estimation of oil concentrations due to sampling variability. In addition, acceptable hydrocarbon concentrations may vary

${ }^{\star}$ Pure Appl. Chem. 71(1) (1999). An issue of special reports reviewing oil spill countermeasures. 
according to the oil type, degree of weathering, and the relative sensitivities of affected organisms. For example, $x$ grams per square metre of fresh crude oil on a marsh may kill all of species $y$ and $50 \%$ of species $z$, but $x$ grams of the same oil stranded on the marsh after weathering at sea may kill nothing.

In the end, however, definitions must include the possibility that petroleum hydrocarbons are present in the environment (albeit in very low concentrations for some situations). It is unlikely that any single definition will serve all interests after a spill. For example, visible residues of weathered oil on a rocky shore may be acceptable from an ecological viewpoint because they are not affecting the normal functioning of the ecosystem. This may not be acceptable, however, from a public amenity viewpoint, and companies fear reprisals if measures are not taken in response to public concerns.

\section{PROCESSES AND TIMESCALES FOR NATURAL CLEANING}

In addition to considering acceptable definitions of clean, the following questions about natural cleaning should be answered as part of the clean-up response plan:

- What are the natural processes promoting cleaning at the site of interest?

- What is the predicted timescale for natural processes to produce an acceptable standard of cleanliness?

- Is the predicted timescale acceptable or too long?

- If too long, can enhanced clean-up accelerate the recovery timescale?

Human intervention in the form of a clean-up response is justified only if the predicted timescale for site recovery is too long.

Processes of natural cleaning including physical dispersion and biodegradation are relatively wellknown and described in the literature (e.g. [3-5]). There also is sufficient case history evidence to give a reasonable indication of natural cleaning timescales in different types of habitat. For open water sites, ITOPF [3] provides graphs illustrating the rate of removal from the water surface of different oil types ranging from the lightest (Group I) oils such as kerosene to the heaviest (Group IV) such as Bunker C oil. The ITOPF model can be expressed in half-lives (the time taken for natural removal of $50 \%$ of the oil from the water surface), and these typically range from about half a day for Group I oils to seven days or more for Group IV oils. However, for large spills near coastlines, some oil typically is stranded on the shore within a few days; once oil is stranded, the natural cleaning timescale may be prolonged.

Selected case histories covering a range of shore conditions are summarised in Baker et al. [6], and examples from rocky shores are given in Fig. 1. Observed timescales range from a few days (some case histories for very exposed rocky shores) to 20-25 years (some case histories for very sheltered marshes). Given that in extreme cases (e.g. [7]) thick deposits of oil may remain after about 20 years, it is reasonable to extrapolate that natural cleaning may take several decades in some sheltered environments. Case history observations form the basis for discussions on factors determining the behaviour of oil on shores (e.g. [8-14]) and are also useful in the production of shore vulnerability or sensitivity indices such as that of Gundlach \& Hayes [15] and others e.g. [16].

Natural cleaning timescales on shores are affected by factors including:

- Exposure of the shore to wave energy, from very exposed rocky headlands to sheltered tidal flats, saltmarshes and mangroves. This in turn depends on a number of variables that include fetch; speed, direction, duration and frequency of winds; and open angle of the shore [17];

- Localised exposure/shelter-even on an exposed shore, cracks, crevices, and spaces under boulders can provide sheltered conditions where oil may persist;

- Steepness/shore profile-extensive, gently sloping shores dissipate wave energy;

- Substrate-oil does not easily penetrate fine sediments, especially if they are waterlogged, but can penetrate shingle, gravel and some sand beaches (e.g. [18,19]);

- Clay-oil flocculation - this process reduces adherence of oil to shore substrates and facilitates natural cleaning, as has been described for Prince William Sound after the Exxon Valdez spill [20]; 


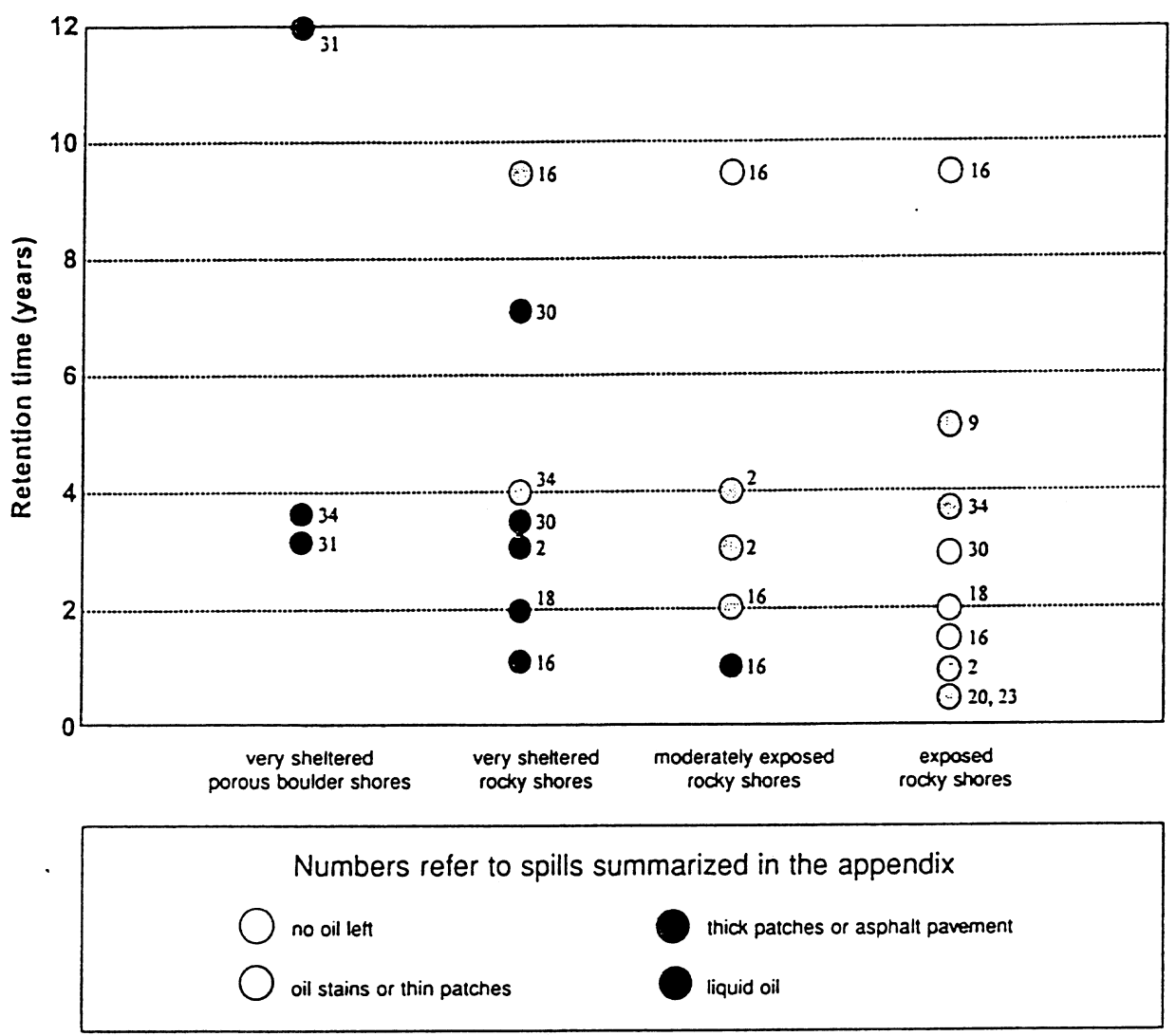

Fig. 1 Oil residence times on a variety of rocky shores where no clean-up has been attempted. Source: adapted from International Petroleum Industry Environmental Conservation Association [36].

- Height of the stranded oil on the shore-oil spots taken into the supratidal zone by spray can persist for many years [21]. Conversely, oil on the middle and lower shore is more likely to be removed by water action. It is common to have stranded oil concentrated in the high tide area (e.g. $[22,23])$;

- Oil type-e.g. viscosity affects movement into and out of sediment shores;

- Volume of oil-e.g. heavy loading may lead to greater retention times in sediments (see [24]).

A further useful reference on the issue of natural cleaning timescales is a paper by Harper et al. [25], on penetration and retention experiments in different sediments treated with different oils.

What should determine whether or not a predicted natural cleaning timescale is unacceptably long and that human intervention is required? Deadlines for return to acceptably clean conditions may emerge after consideration of both ecosystem and human requirements. A British rocky shore may need to be clean by June because it is a breeding area for harbour seals whose first pups are due in June. A sandy beach in Goa (India) may need to be clean by October because of the area's tourist season. In both cases, natural cleaning timescales could be too long and effective clean-up intervention with minimal ecological disruption would be the best option.

More complex considerations arise when there is juxtaposition of sheltered shores with subsurface oil likely to leach out gradually, and nearby fisheries resources (e.g. shellfish beds, fish farms) that may be tainted. On one hand, predicted oil residence times and consequent tainting potential may extend over many years. On the other hand, a thorough, rapid clean-up is likely to be difficult, expensive, aggressive, disruptive to shore structure and possibly lethal to surviving shore organisms. As with definitions of clean, decisions about the acceptability of predicted natural cleaning timescales are a matter for consensus among all interested parties. In many cases, the predicted natural cleaning times may be acceptable, either 
because they are short, or because, even if long, no net environmental benefit can be predicted by intervention.

\section{ECOLOGICAL ADVANTAGES AND DISADVANTAGES OF CLEAN-UP METHODS}

From an ecological point of view, the foremost question is: will the clean-up promote ecosystem recovery? If the answer is no, there is no ecological justification for clean-up intervention, though of course there may be overriding socio-economic considerations as discussed in the next section.

Examination of temperate and cold water case histories as shown in Fig. 2 suggests that ecological recovery times for shorelines are related to shore energy levels (i.e. exposure to wave action). The case histories (see Appendix), which include many examples of both cleaned and untreated shores, have been inserted along the qualitative exposure gradient in Fig. 2 on the basis of site descriptions and/or

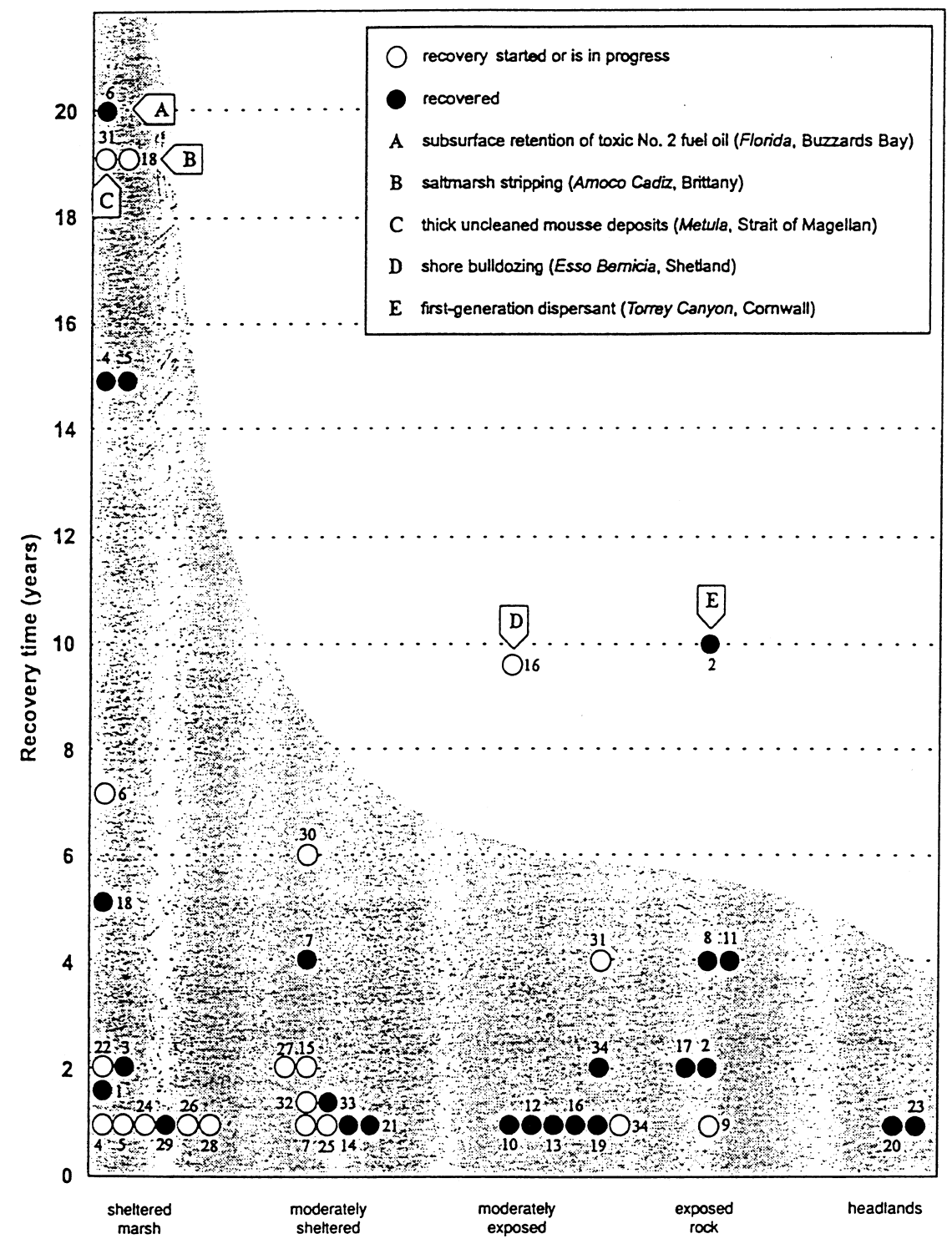

Further information on spills 1 to 34 is given in the Appendix. A to $E$ are extreme cases; see text for further details. Spills have been arranged along an exposure gradient from shettered marsh through shores of intermediate exposure to wave action and various substratum types, to very exposed rocky headlands.

Fig. 2 Biological recovery on shores following a range of temperate and cold water spills. Source: expanded from Baker [94]. Definitions of recovery in Sell et al. [38]. 
maps in the original papers. There are many reports of good recovery within one or two years for the more exposed (mainly rocky) shores, regardless of whether there was clean-up treatment. With sheltered shores within one or two years of oiling, there are more reports of 'recovery started' than reports of 'recovered.' In extreme cases, the recovery times may be much longer for sheltered shores than for exposed shores.

The relationship between shore energy level and recovery times as indicated graphically on Fig. 2 is subjective - it is not documented quantitatively because other variables are involved (e.g. oil type and oil loading). Comparison of Fig. 1 and 2 shows that recovery times do not coincide exactly with oil retention/ natural cleaning times and indicates that recovery can proceed in the presence of some residual oil.

It has not been possible to obtain a range of well documented case histories to produce a similar analysis for tropical shorelines. It seems likely, however, that the relationship between shore energy levels and recovery times also would apply. In particular, there is some evidence that mangrove swamps on very sheltered shorelines absorb and retain oil for considerable periods of time, with concomitant biological effects [26-28].

The longest recovery times shown in Fig. 2 are not consistently related to whether or not clean-up treatment was carried out. Recovery times were long (eight or more years) for three particularly aggressive cases of shore cleaning (labelled B, D and E on Fig. 2); and two extreme cases of oil retention (labelled A and C). These five worst cases are summarised below. An important point: most spills do not present circumstances as extreme as these, and 'typical' recovery times are 1-5 years, with or without clean-up.

\section{Case summaries}

(A) The Florida spill, Buzzards Bay, Massachusetts, 1969. No. 2 fuel oil, which is relatively light and toxic, severely affected a salt marsh where there was substantial subsurface penetration of oil. Apart from damage to the underground systems of plants, oil in the sediments affected marsh invertebrates such as fiddler crabs. Recovery of fiddler crab populations correlated to the gradual disappearance of toxic aromatic hydrocarbons from the sediments, which was not complete after 7 years [29]. After 20 years, the marsh surface was visually normal, but detectable traces of oil remained in some of the sediments [30].

(B) The Amoco Cadiz spill, Brittany, France, 1978. The spill caused heavy oiling of a variety of shores with light Arabian oil mousse. The Ile Grande marshes were cleaned using heavy equipment. As much as $50 \mathrm{~cm}$ of sediment was removed, and, at the same time, channels were widened and straightened. Subsequently it was determined that the treatment had lowered some of the marsh surface to the extent that the sediments were at the wrong intertidal height for plant growth. In 1990, three marshes still had $26 \%, 35 \%$ and $39 \%$ of their prespill surface areas missing. In contrast, an oiled marsh that received no clean-up recovered and increased its vegetated area [31-33].

(C) The Metula spill, Strait of Magellan, Chile, 1974. No clean-up was done after heavy oiling of a variety of shores with light Arabian oil/mousse. One very sheltered marsh received thick deposits of mousse and, in 1993, these deposits still were visible on the marsh surface, with the mousse quite fresh in appearance beneath the weathered surface skin. Little plant recolonisation has occurred in the areas with thicker deposits with a mean oil depth of $4.1 \mathrm{~cm}$ [7].

(D) The Esso Bernicia spill, Sullom Voe, Shetland, 1978. Heavy fuel oil affected rocky and stony shores. In areas where there was no mechanical cleaning, biological communities returned to near normal ranges within the first year. Nine years later, biological communities had not fully recovered on $5 \mathrm{~km}$ of shore where there had been substantial mechanical removal of rocks and gravel [34-36].

(E) The Torrey Canyon spill, SW England, 1967. A range of shores was heavily oiled with Kuwait crude oil/mousse, and many rocky shores received repeated applications of toxic, first-generation dispersants. Biological recovery took at least 10 years on heavily cleaned rocky shores, but only two years on a rocky reef where the dispersants were not used [37]. 
A separate comprehensive comparison of ecological recovery on cleaned vs. untreated rocky shores and saltmarshes has been described by Sell et al. [38]. This fully referenced study analysed adequately documented case histories totalling 34 oil spill case studies and 17 experimental spills (78\% of all case history papers examined were rejected because of insufficient data). The study showed that $85 \%$ of oiled rocky shores and $75 \%$ of oiled salt marshes recovered within three and five years, respectively, regardless of whether they had been cleaned or not. A minority of extreme cases are excluded, these are identified in Fig. 2 and described above. In addition, the Exxon Valdez is a particularly well-documented case in which high-pressure hot-water washing applied in 1989 delayed recovery of rocky shore organisms [39,40].

A unique feature of the study by Sell et al. [38] was that it controlled for recovery rates in the absence of both oil and cleaning by including case histories of experimental and natural clearance of all organisms from defined areas. Such case histories are, however, limited. Natural recovery times for control rocky shores and saltmarshes were found to be about three years and five years, respectively.

It is concluded from these studies that for most spills, those that do not reach the extremes of either oiling intensity or aggressive clean-up, shore cleaning has little effect on recovery rates of shore organisms. Moreover, for most spills it is unreasonable to expect cleaning to reduce recovery timescales significantly below three and five years for rocky shores and saltmarshes (encompassing the extremes of exposed and sheltered shores, respectively), simply because most natural recovery processes of immigration, settlement and growth cannot be accelerated. Therefore, on a shore ecology basis alone, there is little justification for clean-up operations on most oiled rocky shores or saltmarshes.

Interacting systems, however-systems that use or are related to the shore in some way but are not generally regarded as permanent shore features-may take precedence when considering clean-up. Ecological interacting systems include:

- Colonies of birds that nest near the shore but sometimes visit the intertidal zone or feed in nearshore waters that may receive oily run-off from a polluted shore.

- Marine mammals, e.g. seals that use the shore as a haul-out and breeding area.

- Nearshore habitats such as coral reefs, sea grass beds, and kelp beds, which may receive oily run-off from a polluted shore.

- Salmon streams which debouche over the shore, requiring salmon entering a stream to swim over an oily shore at high tide.

Prince William Sound is rich in examples, which in some cases provided justification for shore cleanup after the Exxon Valdez. For example, seal haul-out sites, with birth of pups in May and June, had high priority for clean-up after oiling in March 1989 [41].

Analyses of case histories show that in extreme cases natural recovery times may be 20 years or more on heavily oiled, sheltered shores. On the other hand, aggressive clean-up of Brittany marshes after the Amoco Cadiz spill resulted in a prolonged recovery time of $20+$ years. What would happen if it were necessary to deal with a new case of very thick oil deposits on a saltmarsh? Because neither natural cleanup nor aggressive treatment provides the best environmental benefit, it seems that the greatest benefit would result from a moderate level of clean-up—sufficient to remove most of the bulk oil, but gentle enough to leave the surface of the shore intact and to avoid churning oil into underlying sediments. This can be achieved by using small crews and avoiding the use of heavy machinery as far as possible. The appearance of the shore after such treatment is likely to be somewhat oily and therefore not optimal from an aesthetic viewpoint, but there are numerous examples of biological recovery taking place in the presence of weathered oil remnants [6]. If plants were smothered to death before removal of the bulk oil, replanting schemes can be helpful [32].

Another issue is that information on natural recovery timescales and clean-up plans should be quickly and clearly disseminated to the public in order to avoid unnecessary worry and negative reactions. Consider the following scenario, which has happened on more than one occasion. A northern hemisphere temperate zone saltmarsh dominated by the robust grass Spartina is oiled in October or November, such that the grass is blackened by absorbed oil films (but without thick deposits on the marsh sediments or significant penetration of light toxic oil into the sediments). The Spartina has a natural annual cycle of 
summer growth and winter die-back, and at this time of year the shoots are dying back naturally, with no new growth expected until the spring. It is predicted with this degree of oiling that good new growth will occur in the spring and that no clean-up response is necessary (assuming no overriding needs of interacting systems). In the meantime the blackened dead shoots will be visible for several months with no signs of recovery, suggesting to those unfamiliar with Spartina biology that the marsh has been completely destroyed and urgent action is needed. Is it justifiable to spend money and possibly incur trampling damage to the marsh in order to cut and remove the oily shoots to no ecological or economic purpose? Perhaps the primary effort should focus on discussing marsh ecology and recovery timescales from previous spills with the interested parties.

The final issue of this section concerns the definition of ecological recovery. Given the difficulties of knowing what prespill conditions were, and how to interpret them in the face of natural ecological fluctuations and trends, is it realistic to define recovery as a return to prespill conditions? This definition takes these problems into account:

'Recovery is marked by the re-establishment of a healthy biological community in which the plants and animals characteristic of that community are present and functioning normally. It may not have the same composition or age structure as that which was present before the damage, and will continue to show further change and development. It is impossible to say whether an ecosystem that has recovered from an oil spill is the same as, or different from, that which would have persisted in the absence of the spill' [6].

\section{RELATIONSHIPS BETWEEN ECOLOGICAL AND SOCIO-ECONOMIC CONSIDERATIONS}

The type and degree of clean-up often is influenced not only by ecological considerations but also by socio-economic factors, including various amenity and economic uses of shorelines and coastal waters, aesthetic and idealistic concepts about clean and pristine environments, and political pressures. Consider this scenario: a harbour containing several million dollars of fishing and pleasure boats generates considerable income for the local economy and so is considered a priority area for protection or clean-up. Even if clean-up is achieved quickly, bad publicity can lead to vacation cancellations and subsequent economic loss. In practical terms, boats cannot be cleaned until the oil has been cleaned from the surrounding environment (e.g. beaches, harbour walls and jetties). Any delay can make things worse; staining of boats becomes more severe, and damage can be done to some types of hull material if oil remains in contact for some time.

A spill also means lost fishing opportunities if fishermen are unable or unwilling to fish because of the risk of fouling boats and gear, or tainting the catch. Finfish and shellfish exposed to crude oil or its products may become tainted and unfit for sale if oil-derived substances absorbed by the tissues impart unpleasant odours and flavours. Taint of fish and shellfish can be a compelling reason for environmental clean-up in some cases (e.g. aggressive clean-up of a porous oil-soaked stony shore where oil is leaching and causing taint of nearshore farmed fish). There may be conflicting interests when dealing with oil spills and few clean-up responses can fulfil all the requirements of all interested parties. The following list covers a range of scenarios:

- The area contains resources that are mainly of ecological interest, so there is little conflict with most socio-economic interests. In some areas, however, there is a conflict between shore ecologists who believe that recovery of shores is best advanced by leaving them alone, and other people with various environmental and wilderness interests (e.g. hiking and bird watching) who want as much oil as possible removed.

- The area contains both ecological and socio-economic resources and the optimum response for all resources is the same. For example, a mangrove swamp may be of importance both ecologically and for shellfishing. In both cases the priority is to prevent or reduce the amount of oil entering the mangroves (perhaps by using deflective booming onto a 'sacrificial' easily cleaned sandy beach). Moreover, if oil did enter the swamp it should be relatively easy to agree that nonaggressive techniques such as low pressure ambient temperature water flushing would benefit both interests. 
- The area contains both ecological and socio-economic resources, but the optimum response for one is not the optimum response for the other. For example, the area contains both birds and fish. Dispersant spraying might be the best way of reducing the threat to birds, but would increase the risk of fish tainting.

The contingency planning process should identify such areas of potential conflict and attempt to resolve them before any spill, with consultation between all the interested organisations. A guide to contingency planning including the roles of different organisations and response team members, and proposals for plan sections and subsections, is provided by IPIECA [42]. It is worth considering the rationale of Lindstedt-Siva [43], who used ecological criteria to define environmental sensitivity. This reasoning was on the grounds that 'ecological impacts are both longer lasting and, once they have occurred, harder to repair than most other kinds of impacts (e.g. aesthetic, economic)'.

\section{NET ENVIRONMENTAL BENEFIT ANALYSIS}

There is no doubt that both oil spills and some clean-up responses to spills can damage the flora and fauna or their habitats. The advantages and disadvantages of clean-up responses should be weighed and compared with the advantages and disadvantages of natural clean-up. A net environmental benefit analysis (NEBA) is essential. The NEBA process typically involves the following:

- Collect information on ecology, physical characteristics, and human use of environmental resources of the area proposed for clean-up, and details of the proposed clean-up method.

- Review previous spill case histories and experimental results which are relevant to the area and clean-up method being assessed.

- On the basis of previous experience, predict the likely environmental outcomes if the proposed cleanup method is used, and if the area is left for natural clean-up.

- Compare the advantages and disadvantages of the proposed clean-up with those of natural clean-up.

- Weigh advantages and disadvantages with reference to the ecological value and human use of environmental resources, to arrive at the optimum clean-up response. All parties must accept that the optimum response often cannot avoid all disadvantages.

Figure 3 illustrates an example of NEBA built into a decision tree for evaluating the requirement for shore clean-up. This figure builds upon work done in the aftermath of the Exxon Valdez incident that included a study on the advisability of excavation and washing of rocks on shores with subsurface oil [44]. The study concluded that the proposed treatment would indeed remove subsurface oil but it did not offer a net environmental benefit because it would alter the shore structure and delay biological recovery (which already had begun). In this case, the negative aspects of the proposed clean-up were not judged to be outweighed by either the positive aspects of clean-up treatment or negative aspects of no treatment.

The NEBA process takes time, which may be available in the case of some oiled shoreline scenarios, but which will not be available for typical nearshore scenarios (e.g. a slick moving over shallow water toward a mangrove swamp). It is therefore important to use NEBA as far as possible during the contingency planning process, before a spill occurs. The following two scenarios provide examples of NEBA considerations:

Scenario 1. Consider a stony shore with subsurface oil that gradually is leaching into the nearshore waters. Information collected for the NEBA shows that near the shore are shallow subtidal beds of shellfish that were used for food by local people before the spill. Biological recovery on the shore has started (e.g. there are algal sporelings and there has been some settlement of new barnacles) but the shellfish are tainted. It is predicted that if the shore is not thoroughly cleaned, some tainting will continue for up to five years, making the shellfish inedible for this period of time. Does this justify aggressive removal of the oil?

From an ecological point of view, there is no justification - previous case history evidence (e.g. [35]) indicates that the recovery of the shore would be set back. Moreover, it is unlikely that there would be any purely ecological benefit to the shellfish populations, which can survive even though they are tainted. 


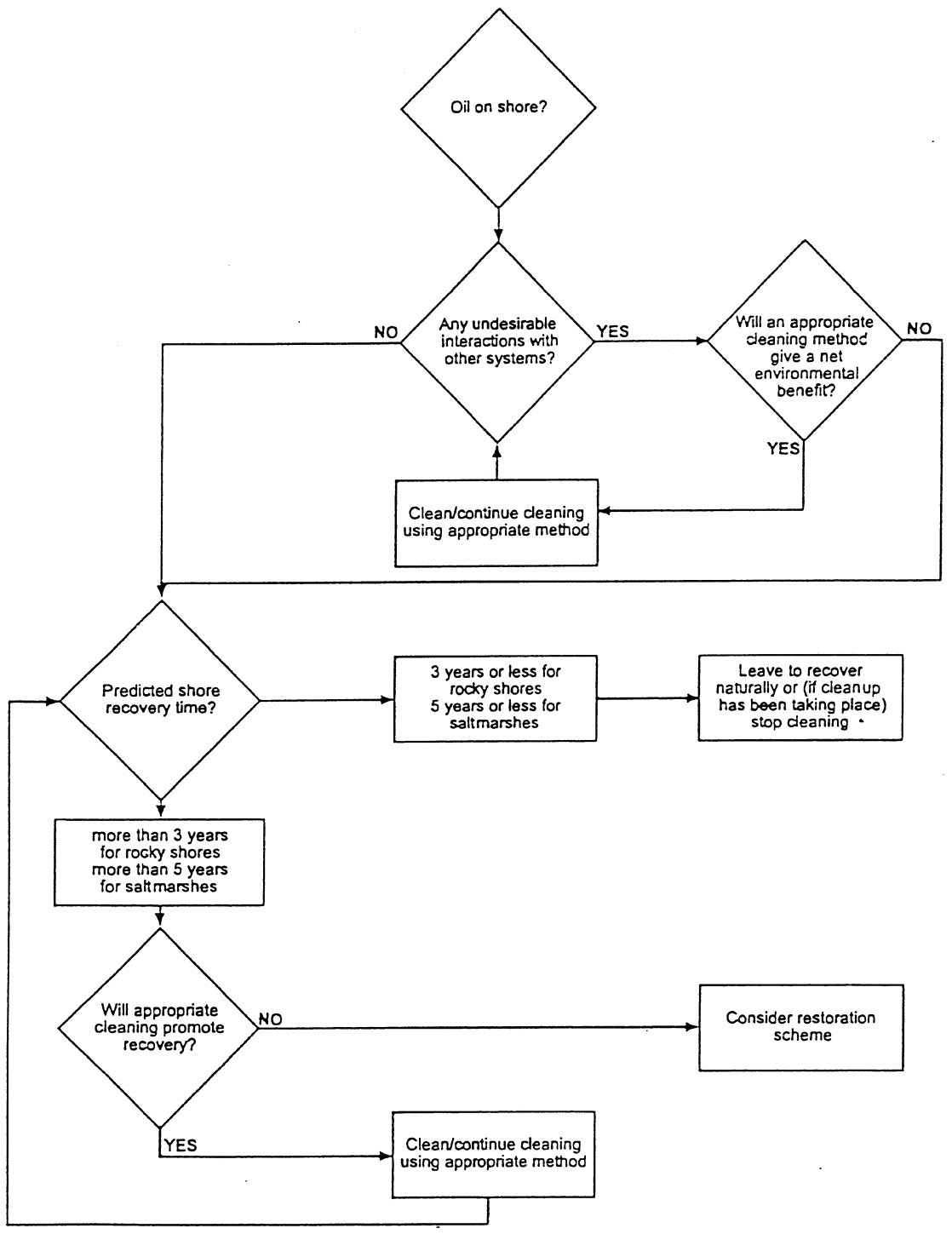

Fig. 3 Decision tree for evaluating the requirement for shore clean-up. Source: from Sell et al. [38].

However, there would be a benefit for the people who collect shellfish as food if the source of tainting was removed as quickly as possible. The main problem for the NEBA is weighing the disadvantages of aggressive clean-up to the shore organisms against the advantages for use of an environmental resourcethe shellfish. There would have to be a compelling socio-economic benefit of clean-up to override the ecological point of view, but in some cases (depending on the size and importance of the shellfishery), the socio-economic consideration might justifiably prevail. This might include cultural factors, such as subsistence use of shellfisheries.

Scenario 2. Consider a slick moving over shallow nearshore water in which there are coral reefs of particular conservation interest. The slick is moving toward sandy beaches important for tourism. Assume that the only logistically feasible response is aerial dispersant spraying. This should minimise pollution of the beaches, but it is predicted that some coral species will be damaged by dispersed oil. From an ecological point of view it is best not to use dispersants but to allow the oil to strand on the beaches, from where it may be quickly and easily cleaned using front-end loaders and crews with hand tools. If dispersants are used, damaged corals could take many years to recover. Widespread degradation of fringing reefs could in turn alter the dynamics of nearby sandy beaches, with possible adverse consequences. 
A closer look at the subject of dispersant use in shallow tropical waters provides some interesting examples of the potential complexity of NEBA considerations. The TROPICS experiment [45] compared the effects of untreated and chemically dispersed oil in an area with mangroves, seagrass beds and corals. The average water depth was less than $1 \mathrm{~m}$, and concentrations of dispersed oil reached as high as 222 p.p.m. With the dispersed oil treatment, there were declines in the abundance of corals and other reef organisms, reduced coral growth rate in one species, and minor effects on seagrasses and mangroves. Fresh, untreated oil had severe effects on survival of mangroves and associated fauna, and minor effects on seagrasses, corals and associated organisms. However, it would be premature to jump to the conclusion that not using dispersants would be the best action if corals were considered to be the highest priority. The Panama oil spill $[46,47]$ provides further essential information. In this case, untreated oil caused damage to both mangroves and corals, including corals at a greater depth $(3-6 \mathrm{~m})$ than those affected in the TROPICS experiment. Branching corals appear more susceptible than massive corals, and recovery has been slow. The impacts on corals have been attributed to the slow release of oil from nearby mangrove sediments, and subsequent depression of coral viability because of the chronic low-level contamination of nearshore waters [46].

Further information on field experiments that provide useful input to NEBA for dispersant use [48-53] is summarised in [54].

NEBA has been advocated as part of the overall contingency planning process [55] on the grounds that postspill decisions are best and most rapidly made in the light of prespill analyses, consultations and agreements by all the appropriate organisations. NEBA needs to be built into the process of evaluating requirements for clean-up, particularly for evaluating techniques for which there is a window of opportunity for only one or two days. General principles include:

- Conflicts of interest are inevitable. They may include conflicts between different ecological interests, e.g. coral reefs that may be damaged if dispersants are used to treat floating slicks, vs. birds that may be saved by the same treatment.

- Consideration should be given both to the shore itself and the ecological and socio-economic systems that interact with the shore in some way, such as bird colonies or nearshore fisheries.

- Aggressive clean-up can drastically alter shore habitats and prolong recovery times of shore biota. Such clean-up can, however, be justified for the sake of an interacting system.

- In most cases of shore oiling where moderate clean-up is considered likely to reduce the threat to interacting systems, the evidence (from rocky shores and saltmarshes) is that moderate clean-up will not make a significant difference to the shore biological recovery times.

\section{CONCLUSIONS}

Three main themes emerge from this review:

- There are many different definitions of clean, drawing upon both ecological and socio-economic criteria. There is no 'best' definition. Different definitions may be applicable to different spills, or different areas oiled by the same spill. Initiation of a clean-up response, or decision to leave an area for natural clean-up, needs to be focused on one or more definitions, otherwise there is no yardstick for assessing if the clean-up has achieved the desired result.

- There is no 'best' clean-up method. The ecological and socio-economic advantages and disadvantages of different clean-up responses in any area should be weighed using the net environmental benefit approach. As this takes time, it is best done before a spill as part of the contingency planning process.

- Decisions regarding definitions of clean and assessment of net environmental benefit for clean-up methods need to be reached through consensus, involving all interested parties during the contingency planning process. Decisions need to be well-informed, and there is a continuing need for education, better communication, and constructive involvement of the media.

While these points address ecological and socio-economic considerations, there remains the need to balance these with 'operational feasibility', that is, the practicality and feasibility of the proposed actions to 
achieve the ecological objective. Further, while it is advantageous to use contingency planning to define 'clean', to select the best clean-up methods and to determine the net environmental benefit, these actions must be re-evaluated, or 'tuned' at the time of the spill, taking into consideration real time conditions.

\section{ACKNOWLEDGEMENTS}

The following people are gratefully acknowledged for their assistance: Ron Elliott, Jon Moore, Cordah Ltd, Neyland, UK, and Ed Owens, Polaris Applied Sciences Inc., Bainbridge Island, Washington, USA. Figures 2 and 3 are based on work done by the author for the UK Institute of Petroleum and Aberdeen University Research and Industrial Services (now incorporated in Cordah), respectively; the author thanks these organisations for allowing them to be included. The paper as a whole is based on an issue paper [2] presented at the 1997 International Oil Spill Conference sponsored by the US Coast Guard, the US Environmental Protection Agency, the American Petroleum Institute, the International Petroleum Industry Environmental Conservation Association, and the International Maritime Organization.

\section{REFERENCES}

1 E. P. Myers, C. G. Gunnerson. Hydrocarbons in the Ocean. US Dept. of Commerce (NOAA), Washington, DC (1976).

2 J. M. Baker. How Clean is Clean? Issue paper presented at the 1997 International Oil Spill Conference. American Petroleum Institute, Washington, DC (1997).

3 ITOPF. Response to marine oil spills. International Tanker Owners Pollution Federation Ltd, Witherby Ltd, London (1987).

4 R. E. Jordan, J. R. Payne. Fate and Weathering of Petroleum Spills in the Marine Environment: A Literature Review and Synopsis. Ann Arbor Science Publishers, Inc., Ann Arbor, MI (1980).

5 R. B. Wheeler. The fate of petroleum in the marine environment. Special report, Exxon Product Research Company, Houston, TX (1978).

6 J. M. Baker, R. B. Clark, P. F. Kingston, R. H. Jenkins. Natural recovery of cold water marine environments after an oil spill. Paper presented at the 13th AMOP Technical Seminar. Environmental Protection Service, Environment Canada, Ottawa (1990).

7 J. M. Baker, L. M. Guzman, P. D. Bartlett, D. I. Little, C. M. Wilson. Long-term fate and effects of untreated thick oil deposits on saltmarshes. Proceedings, 1993 Oil Spill Conference. American Petroleum Institute, Washington, DC, pp 395-399 (1993).

8 E. R. Gundlach. Oil-holding capacities and removal coefficients for different shoreline types to computer simulate spills in coastal waters. Proceedings, 1987 Oil Spill Conference, pp. 451-457. American Petroleum Institute, Washington, DC (1987).

9 E. H. Owens. Mechanical dispersal of oil stranded in the littoral zone. J. Fish Res. Board Canada. 35, 563-572 (1978).

10 E. H. Owens. Factors affecting the persistence of stranded oil on low energy coasts. Proceedings, 1985 Oil Spill Conference, pp. 359-365. American Petroleum Institute, Washington, DC (1985).

11 E. H. Owens, B. Humphrey, G. A. Sergy. Natural cleaning of oiled coarse sediment shorelines in Arctic and Atlantic Canada. Spill Science Technol. Bull. 1(1), 37-52 (1994).

12 E. Tsouk, S. Amir, V. Goldsmith. Natural self-cleaning of oil polluted beaches by waves. Mar. Pollut. Bull. 16, 11-19 (1985).

13 J. H. Vandermeulen. Some conclusions regarding long-term biological effects of some major oil spills. Phil. Trans R. Soc. London, B 297, 335-351 (1982).

14 D. A. Wolfe. Interactions of spilled oil with suspended materials and sediments in aquatic systems. In Fate and Effects of Sediment-Bound Chemicals in Aquatic Systems (K. L. Dickson, A. W. Maki, W. A. Brungs, eds.), pp. 299-316. Pergamon Press, New York and Oxford (1987).

15 E. R. Gundlach, M. O. Hayes. Vulnerability of coastal environments to oil spill impacts. Mar. Technol. Soc. J. 12, 18-27 (1978).

16 J. Michel, J. Dahlin. Guidelines for Developing Digital Environmental Sensitivity Index Atlases and Databases. National Oceanic and Atmospheric Administration, Seattle, WA (1993). 
17 W. J. Ballantine. A biologically-defined exposure scale for the comparative description of rocky shores. Field Studies. 1, 1-19 (1961).

18 M. O. Hayes, E. R. Gundlach, L. D’Ozouville. Role of dynamic coastal processes in the impact and dispersal of the Amoco Cadiz oil spill (March 1978), Brittany, France. Proceedings, 1979 Oil Spill Conference, pp. $193-198$. American Petroleum Institute, Washington, DC (1979).

19 B. F. N. Long, J. H. Vandermeulen, T. P. Ahern. The evolution of stranded oil within sandy beaches. Proceedings, 1987 Oil Spill Conference, pp. 519-524. American Petroleum Institute, Washington, DC (1981).

20 H. O. Jahns, J. R. Bragg, L. C. Dash, E. H. Owens. Natural cleaning of shorelines following the Exxon Valdez spill. Proceedings, 1991 International Oil Spill Conference, pp. 167-176. American Petroleum Institute, Washington, DC (1991).

21 D. N. Mottershead. The persistence of oil pollution on a rocky shore. Appl. Geogr. 1, 297-304 (1981).

22 P. D. Keizer, T. P. Ahern, J. Dale, J. H. Vandermeulen. Residues of Bunker C oil in Chedabucto Bay, Nova Scotia, six years after the Arrow spill. J. Fish Res. Board Canada. 35, 582-535 (1978).

23 E. H. Owens, B. Humphrey, D. Hope, W. Robson, J. R. Harper. The fate of stranded oil four years after an experimental spill on a sheltered gravel beach, pp. 473-478. Proceedings, 1987 Oil Spill Conference. American Petroleum Institute, Washington, DC (1987).

24 J. R. Harper, G. A. Miskulin, D. R. Green, D. Hope, J. H. Vandermeulen. Experiments on the fate of oil in low energy marine environments. Proceedings 8th AMOP Technical Seminar, pp. 383-389. Environmental Protection Service, Environment Canada, Ottawa (1985).

25 J. R. Harper, G. Sergy, T. Sagayama. Subsurface oil in coarse sediment experiments (SOCSEX II). Proc. 18th Arctic and Marine Oilspill Program Technical Seminar, pp. 867-886. Environment Canada (1995).

26 J. E. Corredor, J. M. Morell, C. Del Castillo. Persistence of spilled crude oil in a tropical intertidal environment. Mar. Pollut. Bull. 21, 385-388 (1990).

27 S. D. Garrity, S. C. Levings, K. A. Bums. Chronic oiling and long-term effects of the 1986 Galeta spill on fringing mangroves. Proceedings, 1993 Oil Spill Conference, pp. 319-324. American Petroleum Institute, Washington, DC (1993).

28 E. J. Klekowski Jr, J. E. Corredor, I. M. Morell, C. A. Del Castillo. Petroleum pollution and mutation in in mangroves. Mar. Pollut. Bull. 28, 166-169 (1994).

29 C. T. Krebs, K. A. Burns. Long-term effects of an oil spill on populations of the saltmarsh crab Uca pugnax. J. Fish Res. Board Canada. 35, 648-649 (1978).

30 J. M. Teal, J. W. Farrington, K. A. Burns, J. J. Stegeman, B. W. Tripp, B. Woodin, C. Phinney. The West Falmouth oil spill after 20 years: fate of fuel oil compounds and effects on animals. Mar. Pollut. Bull. 24, 607614 (1992).

31 J. H. Vandermeulen, B. F. N. Long, L. D’Ozouville. 1981. Geomorphological alteration of a heavily oiled saltmarsh (Ile Grande, France) as a result of a massive clean-up. Proceedings 1981 Oil Spill Conference, pp. 347-351. American Petroleum Institute, Washington, DC (1981).

32 IPIECA. Biological Impacts of Oil Pollution: Saltmarshes. International Petroleum Industry Environmental Conservation Association, London (1994).

33 E. S. Gilfillan, N. P. Maher, C. M. Krejsa, M. E. Lanphear, C. D. Balls, J. B. Meltzer, D. S. Page. Use of remote sensing to document changes in marsh vegetation following the Amoco Cadiz oil spill (Brittany, France, 1978). Mar. Pollut. Bull. 30, 780-787 (1995a).

34 S. S. C. Westwood, G. M. Dunnet, K. Hiscock. Monitoring the Sullom Voe terminal. In Ecological Impacts of the Oil Industry (ed. B. Dicks), 261-285. John Wiley \& Sons, Chichester and New York, on behalf of the Institute of Petroleum (1989).

35 R. G. Rolan, R. Gallagher. Recovery of intertidal biotic communities at Sullom Voe following the Esso Bernicia oil spill of 1978. Proceedings, 1991 Oil Spill Conference, pp. 461-465. American Petroleum Institute, Washington, DC (1991).

36 IPIECA. Biological Impacts of Oil Pollution: Rocky Shores. International Petroleum Industry Environmental Conservation Association, London (1995).

37 A. J. Southward, E. C. Southward. Recolonization of rocky shores in Cornwall after use of toxic dispersants to clean up the Torrey Canyon spill. J. Fish Res. Board Canada. 35, 682-706 (1978).

38 D. Sell, L. Conway, T. Clark, G. B. Picken, J. M. Baker, G. M. Dunnet, A. D. McIntyre, R. B. Clark. Scientific 
criteria to optimize oil spill clean-up. Proceedings, 1995 International Oil Spill Conference, pp. 595-610. American Petroleum Institute, Washington, DC (1995).

39 J. P. Houghton, A. K. Fukuyama, D. C. Lees, W. B. Driskell, G. Shigenaka, A. J. Mearns. Impacts on intertidal epibiota: Exxon Valdez spill and subsequent clean-up. Proceedings, 1993 International Oil Spill Conference, pp. 293-300. American Petroleum Institute, Washington, DC (1993).

40 J. P. Houghton, R. H. Gilmour, D. C. Lees, W. B. Driskell, S. C. Lindstrom, A. J. Mearns. Prince William Sound intertidal biota seven years later: has it recovered? Proceedings, 1997 International Oil Spill Conference, pp. 679-686. American Petroleum Institute, Washington, DC (1997).

41 L. F. Lowry, K. J. Frost, K. W. Pitcher. Observations of oiling of harbour seals in Prince William, Sound. In Marine Mammals and the Exxon Valdez (T. R. Loughlin, ed.), pp. 209-225. Academic Press Inc, San Diego and London (1994).

42 IPIECA. A Guide to Contingency Planning for Oil Spills on Water. International Petroleum Industry Environmental Conservation Association, London (1991).

43 J. Lindstedt-Siva. Environmental sensitivity, protection and planning. Proceedings, Sixth Information Transfer Meeting, pp. 21-25. Pacific OCS Region, Minerals Management Service (1991).

44 NOAA. Excavation and Rock Washing Treatment Technology: Net Environmental Benefit Analysis. National Oceanic and Atmospheric Administration, Seattle (1990).

45 T. G. Ballou, S. C. Hess, R. E. Dodge, A. H. Knap, T. D. Sleeter. Effects of untreated and chemically dispersed oil on tropical marine communities: a long-term field experiment. Proceedings, 1989 Oil Spill Conference, pp. 447-454. American Petroleum Institute, Washington, DC (1989).

46 IPIECA. Biological Impacts of Oil Pollution: Coral Reefs. International Petroleum Industry Environmental Conservation Association, London (1992).

47 I. D. Cubit, J. L. Connor. Effects of the 1986 Bahia Las Minas oil spill on reef flat communities. Proceedings, 1993 Oil Spill Conference, pp. 329-334. American Petroleum Institute, Washington, DC (1993).

48 E. S. Gilfillan, D. S. Page, S. A. Hanson, J. C. Foster, J. R. Hotham, D. Vallas, R. Gerber, S. D. Pratt. Effect of spills of dispersed and non-dispersed oil on intertidal infaunal community structure. Proceedings, 1983 Oil Spill Conference, pp. 457-463. American Petroleum Institute, Washington, DC (1983).

49 E. S. Gilfillan, D. S. Page, S. A. Hanson, J. C. Foster, J. R. Hotham, D. Vallas, R. Gerber. Effects of test spills of chemically dispersed and non-dispersed oil on the activity of aspartate amino-transferase and glucose-6phosphate dehydrogenase in two intertidal bivalves, Mya arenaria and Mytilus edulis. In Oil Spill Chemical Dispersants: Research, Experience, Recommendations, STP 840 (T. E. Allen, ed.), pp. 299-313. American Society for Testing and Materials, Philadelphia (1984).

50 H. C. Lai, M. C. Feng. Field and laboratory studies on the toxicity of oils to mangroves. Proceedings, 1985 Oil Spill Conference, pp. 539-546. American Petroleum Institute, Washington, DC (1985).

51 S. Legore, D. S. Marszalek, L. J. Danek, M. S. Tomlinson, J. E. Hofmann, J. E. Cuddeback. Effect of chemically dispersed oil on Arabian gulf corals: a field experiment. Proceedings, 1985 Oil Spill Conference, pp. 375-380. American Petroleum Institute, Washington, DC (1989).

52 D. S. Page, J. C. Foster, J. R. Hotham, E. Pendergast, S. Hebert, L. Gonzalez, E. S. Gilfillan, S. A. Hanson, R. P. Gerber, D. Vallas. Long-term fate of dispersed and undispersed crude oil in two nearshore test spills. Proceedings 1983 Oil Spill Conference, pp. 465-471. American Petroleum Institute, Washington, DC (1983).

53 G. A. Sergy, P. J. Blackall. Design and conclusions of the Baffin Island oil spill project. Arctic 40(Suppl. 1), 1-9 (1987).

54 J. M. Baker. Net environmental benefit analysis for oil spill response. Proceedings, 1995 International Oil Spill Conference, pp. 611-614. American Petroleum Institute, Washington, DC (1995).

55 IPIECA. Dispersants and their Role in Oil Spill Response. International Petroleum Industry Environmental Conservation Association, London (1993).

56 E. B. Cowell, J. M. Baker. Recovery of a saltmarsh in Pembrokeshire, S.W. Wales, from pollution by crude oil. Biol. Conservation. 1, 291-295 (1969).

57 J. E. Smith, ed. Torrey Canyon Pollution and Marine Life. Cambridge University Press (1968).

58 R. E. Stebbings. Recovery of saltmarsh in Brittany sixteen months after heavy pollution by oil. Environ. Pollut. 1, 63-167 (1970).

59 J. M. Baker. Studies on saltmarsh communities. In The Ecological Effects of Oil Pollution on Littoral 
Communities (E. B. Cowell, ed.), pp. 16-101. Applied Science Publishers, Barking, on behalf of the Institute of Petroleum (1971).

60 G. Hobbs, C. I. Morgan. A Review of the Current State of Environmental Knowledge of the Milford Haven Waterway. Field Studies Council, Pembroke. FSC/RC/5/92 (1992).

61 R. C. Clark Jr, B. G. Patten, E. E. De Nike. Observations of a cold-water intertidal community after five years of a low-level persistent oil spill from the General M.C. Meigs. J. Fish Res. Board Canada. 35, 754-765 (1978).

62 W. J. Cretney, C. S. Wong, D. R. Green, C. A. Bawden. Long-term fate of a heavy fuel oil in a spillcontaminated B.C. coastal bay. J. Fish Res. Board Canada. 35, 521-527 (1978).

63 R. A. A. Blackman, J. M. Baker, J. Jelly, S. Reynard. The Dona Marika oil spill. Mar. Pollut. Bull. 4, 181-183 (1973).

64 B. Dicks, J. P. Hartley. The effects of repeated small oil spillages and chronic discharges. Phil. Trans. R. Soc. London B. 297, 285-307 (1982).

65 J. M. Baker, K. Hiscock. Predicting the impact of oil terminal development on the in-shore marine environment: retrospective analysis. In Planning and Ecology (R. D. Roberts, T. M. Roberts, eds), pp. 422-438. Chapman \& Hall, London (1984).

66 J. W. Anderson, R. G. Riley, R. M. Bean. Recruitment of benthic animals as a function of petroleum hydrocarbon concentrations in the sediment. J. Fish Res. Board Canada. 35, 679-680 (1978).

67 H. E. Clifton, K. A. Kvenvolden, J. B. Rapp. Spilled oil and infaunal activity-modification of burrowing behaviour and redistribution of oil. Mar Environ. Res. 11, 111-136 (1984).

68 J. R. Shears. The Environmental Assessment of Oil Pollution. PhD Thesis, University of Southampton (1990).

69 R. A. A. Blackman, R. J. Law. The Eleni V oil spill: Return to normal conditions. Mar. Pollut. Bull. 12, 126130 (1981).

70 E. R. Gundlach, S. Berne, L. D’Ozouville, J. A. Topinka. Shoreline oil two years after Amoco Cadiz: new complications from Tanio. In Proceedings of the 1981 Oil Spill Conference, pp. 525-534. American Petroleum Institute, Washington, DC (1981).

71 B. J. Baca, T. E. Lankford, E. R. Gundlach. Recovery of Brittany coastal marshes in the eight years following the Amoco Cadiz incident. Proceedings, 1987 Oil Spill Conference, pp. 459-464. American Petroleum Institute, Washington, DC (1987).

72 D. S. Page, J. C. Foster, E. S. Gilfillan. Kinetics of aromatic hydrocarbon depuration by oysters impacted by the Amoco Cadiz spill. In Fate and Effects of Oil in Marine Ecosystems (J. Kuiper, W. J. Van den Brink, eds), pp. 243-251. Martinus Nijhoff, Dordrecht (1987).

73 J. H. Crothers. Field experiments on the effects of crude oil and dispersant on the common animals and plants of rocky sea shores. Mar. Environ. Res. 8, 215-239 (1983).

74 J. M. Baker, J. H. Crothers, D. I. Little, J. H. Oldham, C. M. Wilson. Comparison of the fate and ecological effects of dispersed and nondispersed oil in a variety of intertidal habitats. In Oil Spill Chemical Dispersants: Research, Experience and Recommendations, STP 840 (T. E. Allen, ed.), pp. 239-279. American Society for Testing and Materials, Philadelphia, PA (1984).

75 O. Linden, J. Mattsson, M. Notini. A spill of light fuel oil in the Baltic Sea. In Proceedings, 1983 Oil Spill Conference, pp. 517-520. American Petroleum Institute, Washington, DC (1983).

76 S. Forbes, B. Barnett. Preliminary report on the routine intertidal survey of the south bank of the Humber estuary, August 1983 and 1984, with special reference to the Sivand oil spill. Report no. SF/BB/Sc.Rep./85.2, Anglian Water Authority, Elsham, South Humberside (1985).

77 D. I. Little. Oiled sediments in the Humber estuary following the Sivand incident. In Proceedings, 1987 Oil Spill Conference, pp. 419-426. American Petroleum Institute, Washington, DC (1987).

78 W. M. Blaylock, J. P. Houghton. Infaunal recovery at Ediz Hook following the Arco Anchorage oil spill. In Proceedings of the 1989 Oil Spill Conference, pp. 421-426. API Publication no. 4479, American Petroleum Institute, Washington, DC (1989).

79 S. Howard, J. M. Baker, K. Hiscock. The effects of oil and dispersants on seagrasses in Milford Haven. In Ecological Impacts of the Oil Industry (B. Dicks, ed.), pp. 61-96. John Wiley and Sons, Chichester and New York, on behalf of the Institute of Petroleum (1989).

80 D. I. Little, A. E. Little. Estuarine oil spill effects in the context of dispersant use changes. Proceedings, 1991 International Oil Spill Conference, pp. 519-524. American Petroleum Institute, Washington, DC (1991). 
81 E. S. Gilfillan, J. H. Vandermeulen. Alterations in growth and physiology of softshell clams, Mya arenaria, chronically oiled with Bunker C from Chedabucto Bay, Nova Scotia, 1970-1976. J. Fish Res. Board Canada. 35, 630-636 (1978).

82 D. C. Gordon Jr, J. Dale, P. D. Keizer. Importance of sediment working by the deposit-feeding polychaete Arenicola marina on the weathering rate of sediment-bound oil. J. Fish Res. Board Canada. 35, 591-603 (1978).

83 M. H. L. Thomas. Comparison of oiled and unoiled intertidal communities in Chedabucto Bay, Nova Scotia. J. Fish Res. Board Canada. 35, 707716 (1978).

84 D. Straughan. Biological studies of the Metula oil spill. Proceedings, Conference on Assessment of Ecological Impacts of Oil Spills, pp. 365-377. American Institute of Biological Sciences, Washington, DC (1978).

85 L. Guzinan, I. Campodonico. Studies after the Metula spill in the Straits of Magellan. Proceedings of the Petromar 1980 Conference, pp. 363-376. Graham and Trotman, London (1981).

86 E. H. Owens, W. Robson, B. Humphrey. Observations and initial results from a site visit to the Metula spill 12.5 years after the incident. Proceedings, 10th AMOP Technical Seminar, pp. 21-41. Environmental Protection Service, Environment Canada, Ottawa (1987).

87 O. Linden, R. Elmgren, P. Boehm. The Tsesis oil spill: its impact on the coastal ecosystems of the Baltic Sea. Ambio. 8(244), 253 (1979).

88 M. Notini. Impact of oil on the littoral ecosystem. In The Tsesis Oil Spill (J. J. Kineman, R. Elmgren, S. Hanson. eds) , pp. 129-145. US Department of Commerce (NOAA), Washington, DC (1980).

89 P. D. Boehm, J. E. Barak, D. L. Fiest, A. A. Elskus. A chemical investigation of the transport and fate of petroleum hydrocarbons in littoral and benthic enviromnents: the Tsesis oil spill. Mar Environ. Res. 6, 157-188 (1982).

90 E. Bonsdorff. The Antonio Gramsci oil spill: impact on the littoral and benthic ecosystems. Mar. Pollut. Bull. 12, 301-305 (1981).

91 E. S. Gilfillan, D. S. Page, E. J. Harner, P. D. Boehm. Shoreline ecology program for Prince William Sound, Alaska, following the Exxon Valdez oil spill. Part 3-biology. In Exxon Valdez Oil Spill: Fate and Effects in Alaskan Waters (P. G. Wells, J. N. Butler, J. S. Hughes. eds), pp. 398-443. American Society for Testing and Materials, Philadelphia, PA (1995).

92 J. Michel, M. O. Hayes. Persistence and weathering of Exxon Valdez oil in the intertidal zone-3 years later. Proceedings, 1993 International Oil Spill Conference, pp. 279-286. American Petroleum Institute, Washington, DC (1993).

93 M. Notini. Long-term effects of an oil spill on Fucus macrofauna in a small Baltic bay. J. Fish Res. Board Canada. 35, 745-753 (1978).

94 J. M. Baker. Fate and effects of marine oil pollution in UK waters. Report to the Institute of Petroleum, London (1993). 


\section{APPENDIX}

\section{Key to references for Figs 1 and 2}

Numbers 1-29 are temperate water spills, 30-34 are cold water spills. Where the same number appears more than once on a Figure, this refers to different shores affected by the same spill.

\begin{tabular}{|c|c|c|}
\hline Number on figure/incident & Information summary & References \\
\hline 1. Chryssi P. Goulandris & $\begin{array}{l}\text { Mildford Haven, Wales, 1967. Light } \\
\text { Arabian crude on saltmarsh }\end{array}$ & {$[56]$} \\
\hline 2. Torrey Canyon & $\begin{array}{l}\text { SW England and Brittany, 1967. Kuwait } \\
\text { crude on rocky shores and saltmarsh }\end{array}$ & {$[37,57,58]$} \\
\hline 3. Field experiment & $\begin{array}{l}\text { Milford Haven, Wales, 1968. Kuwait crude } \\
\text { on saltmarsh }\end{array}$ & {$[59]$} \\
\hline 4. Field experiment & $\begin{array}{l}\text { S. Wales, 1968. Kuwait crude on upper } \\
\text { saltmarsh }\end{array}$ & {$[32,59]$} \\
\hline 5. Small unattributed spill & $\begin{array}{l}\text { Milford Haven, Wales, 1969. Heavy fuel on } \\
\text { saltmarsh }\end{array}$ & [7] \\
\hline 6. Florida & $\begin{array}{l}\text { Buzzards Bay 1969. No. } 2 \text { fuel oil on } \\
\text { saltmarsh }\end{array}$ & {$[29,30]$} \\
\hline 7. Irini & $\begin{array}{l}\text { S. Baltic Sea, } 1970 . \text { Medium and heavy fuel } \\
\text { oil on rocky shores }\end{array}$ & {$[93]$} \\
\hline 8. Thuntank 6 & $\begin{array}{l}\text { Milford Haven, Wales, 1971. Heavy fuel oil } \\
\text { on rocky shores }\end{array}$ & {$[60]$} \\
\hline 9. General MC Meigs & $\begin{array}{l}\text { NW Washington State, 1972. Navy fuel oil } \\
\text { on rocky shores }\end{array}$ & {$[61]$} \\
\hline 10. Irish Stardust & $\begin{array}{l}\text { British Columbia, 1973. No. } 5 \text { fuel oil on a } \\
\text { variety of shores }\end{array}$ & {$[62]$} \\
\hline 11. Dona Marika & $\begin{array}{l}\text { Milford Haven, Wales, 1973. Petrol } \\
\text { (gasoline) on rocky shores }\end{array}$ & {$[63,64]$} \\
\hline 12. Universe Leader & $\begin{array}{l}\text { Bantry Bay, Ireland, 1974. Kuwait crude on } \\
\text { rocky shores }\end{array}$ & {$[65]$} \\
\hline 13. Afran Zodiac & $\begin{array}{l}\text { Bantry Bay, Ireland, 1975. Heavy fuel oil on } \\
\text { rocky shores }\end{array}$ & {$[65]$} \\
\hline 14. Field experiment & $\begin{array}{l}\text { Sequim Bay, Washington State. Prudhoe } \\
\text { Bay crude on sediments }\end{array}$ & {$[66]$} \\
\hline 15. Field experiments & $\begin{array}{l}\text { Willapa Bay, Washington State, 1977/78. } \\
\text { North Slope crude on sediments }\end{array}$ & {$[67]$} \\
\hline 16. Esso Bernicia & $\begin{array}{l}\text { Sullom Voe, Shetland, 1978. Heavy fuel oil } \\
\text { on rocky shores }\end{array}$ & {$[34,35,68]$} \\
\hline 17. Eleni $V$ & E. England, 1978. Heavy fuel oil on shingle & {$[69]$} \\
\hline 18. Amoco Cadiz & $\begin{array}{l}\text { Brittany, 1978. Light Arabian crude oil on a } \\
\text { variety of shores }\end{array}$ & {$[31,70-72,33]$} \\
\hline 19. Betelgeuse & $\begin{array}{l}\text { Bantry Bay, Ireland, 1979. Mixed Arabian } \\
\text { crude on rocky shores }\end{array}$ & {$[65]$} \\
\hline 20. Field experiment & $\begin{array}{l}\text { Hurlstone Point, SW England, 1979. Forties } \\
\text { crude on exposed rocky shore }\end{array}$ & {$[73,74]$} \\
\hline 21. Field experiment & $\begin{array}{l}\text { Watchet, SW England, 1979. Forties crude } \\
\text { on sheltered rocky shore }\end{array}$ & {$[74]$} \\
\hline 22. Field experiment & $\begin{array}{l}\text { Steart, SW England, 1979. Forties crude on } \\
\text { saltmarsh }\end{array}$ & {$[74]$} \\
\hline 23. Field experiment & $\begin{array}{l}\text { Hurlstone Point, SW England, } 1981 . \\
\text { Residue and mousse on rocky shore }\end{array}$ & {$[74]$} \\
\hline
\end{tabular}


Appendix continued

Number on figure/incident

24. Field experiment

25. Sefir

26. Sivand

27. Arco Anchorage

28. Field experiment

29. El Omar

30. Arrow

31. Metula

32. Tsesis

33. Antonio Gramsci

34. Exxon Valdez
Information summary

References

Steart, SW England, 1981. Various oils on

[74]

saltmarsh

S. Baltic Sea, 1981. No. 1 fuel oil and diesel on rocky shores

Humbar estuary, England, 1983. Nigerian crude on segiments

Port Angeles, Washington State, 1985.

North slope crude on coarse sediments

Milford Haven, Wales, 1986. Nigerian crude on intertidal seagrass

Milford Haven, Wales, 1988. Iranian crude on saltmarsh

Chedabucto Bay, Nova Scotia, 1970. Heavy fuel oil on a variety of shores

Straight of Magellan, Chile, 1974. Light

Arabian oil/mousse on a variety of shores

$[80,60]$

[81-83]

[7,84-86]

Swedish archipelago, Baltic Sea, 1977. No.

5 fuel oil on rocky shores

[90] rocky shores

Prince William Sound, Alaska, 1989. North Slope crude oil on rocky shores 